\title{
The flow of Islamic finance and economic growth: An empirical evidence of Middle East
}

\author{
Mosab I. Tabash ${ }^{1, ~ *, ~ R a j ~ S . ~ D h a n k a r ² ~}$ \\ ${ }_{2}^{1}$ Faculty of Management Studies (FMS), University of Delhi, Delhi-110007, India \\ Dean and Professor of Finance, Faculty of Management Studies (FMS), University of Delhi, Delhi-110007, India
}

\section{Email address:}

mosubtab@gmail.com (Mosab I. Tabash), rajsdhankar@gmail.com (Raj S. Dhankar)

\section{To cite this article:}

Mosab I. Tabash, Raj S. Dhankar. The Flow of Islamic Finance and Economic Growth: an Empirical Evidence of Middle East. Journal of Finance and Accounting. Vol. 2, No. 1, 2014, pp. 11-19. doi: 10.11648/j.jfa.20140201.12

\begin{abstract}
Islamic finance is one of the fastest growing sectors of the global banking industry and has risen to prominence recently through its distinctive characteristics. The emergence of Islamic finance can be traced back to 1963 in Egypt, while its importance comes to the global financial system only after the global financial crisis occurred in 2008. This paper explores empirically the relationship between the development of Islamic finance and economic growth in the Middle East. Three of the most important countries for Islamic finance growth from Middle East, namely Qatar, Bahrain, and United Arab Emirates (UAE), are selected for the study. To document the relationship between development of Islamic finance and economic growth, annually time-series data of economic growth and Islamic banks' financing were used. We use Islamic banks' financing credited to private sector through modes of financing as a proxy for the development of Islamic finance system and Gross Domestic Product (GDP), as a proxy for economic growth. For the analysis, the unit root test, co-integration test and Granger causality tests were done. Our empirical results generally signify that in the long run Islamic banks' financing is positive and significantly correlated with economic growth in the select countries which reinforces the idea that a well-functioning banking system promotes economic growth. The results obtained from Granger causality test reveals a causal relationship between Islamic finance and economic growth in these countries. It is neither Schumpeter's supply-leading nor Robinson's demand-following. It appears to be a bi-directional relationship from Islamic banks' financing to economic growth and vice versa for Bahrain and Qatar. The results obtained from Granger causality test for UAE indicates that a causal relationship happens only in one direction, i.e., from Islamic banks' financing to economic growth, which supports Schumpeter's supply-leading theory. Our results also indicate that improvement of the Islamic financial institutions in the Middle East countries will benefit from economic development, and it is important in the long run for the economic welfare, and also for poverty reduction. Furthermore, the results of study are quite significant as it is one of the pioneering studies of Islamic finance.
\end{abstract}

Keywords: Islamic Finance, Economic Growth, Middle East, Causality

\section{Introduction}

With global markets suffering from extreme turbulence in the wake of the credit crunch and subsequent banking crisis, it is the time to examine the merits of an alternative banking model which adopts a different attitude to risk and finance, based on the principles of Shariah (The Path, term of Islamic law consists of Islamic instructions based on the Holy Quran and Sunnah). Islamic Banking had grown substantially in the decade, the recent financial shocks and volatility will provide a good opportunity for the sector as non-Muslim bank customers opt for the relative safety of institutions based on the principles of Islam. Islamic banking and finance is well and truly established as one of the world's fastest-growing economic sectors.

Young's World Islamic Banking Competitiveness Report 2013 said global Islamic banking assets, with more than 500 Islamic institutions working in more than 75 countries, are expected to reach U.S $\$ 1.8$ trillion by 2014 , up from the $\$ 1.3 \mathrm{tn}$ of assets held in 2011 .

Islamic finance involves structuring financial instruments and financial transactions to satisfy traditional Muslim strictures against the payment of interest and engaging in gambling. It is a field of growing importance for Muslims, especially in the Middle East and large Muslim population in South-Eastern Asia countries, who 
are uncomfortable with Western-style of financial system and banking, which involve explicit payments of interest. Lately, the Vatican (2009) noted that banks should look at the rules of Islamic finance to restore confidence amongst their clients at a time of global economic crisis.

Recently, Ernst \& Neither the ongoing turmoil in the Middle East nor the Euro Zone debt crisis could prevent Islamic banks in the Middle East from reaching out to new markets and more business. This rapid growth has been fuelled by surging demand for Shariah compliant products not only from financiers in the Middle East and other Muslim countries, but also by investors globally, thus making it a global phenomenon. Despite the financial crisis which has plagued the economies of both industrialized and developing nations, the Islamic finance industry has been flourishing, and has enjoyed a 29 percent growth in assets to reach more than U.S.\$ 600 billion in 2008 (Figure1). The performance and relative stability of Islamic financial institutions during the financial crisis that hit the world in 2008 stems from the distinctive features of the instruments they offer. The impressive growth rate of Islamic finance and its stability during financial crisis attract the attention of many policy makers and financial specialties worldwide.

There is no doubt that financial sector development plays an important role in the overall development of an economy. Many economists have maintained that development and efficiency of the financial system are closely linked to economic growth and have pointed out various channels through which the financial system affects economic growth. Most of the empirical studies on the topic find a positive relationship between financial sector development and economic growth, one way to study the role of the financial system in the economy is to examine its functions and the implications of these functions on growth.

Despite there are many empirical studies that examined the relationship between finance and economic growth, but specific empirical studies on the relationship between Islamic finance and economic growth, are not too many.

So, The present study tries to asses empirically the relationship between the development of Islamic finance system and economic growth and its direction in the selected countries of Middle East. We believe that the results of this research will help decision makers and finance scholars to understand the advantages of Islamic finance in enhancing economic growth of any country and to develop sound polices to utilize it.

The layout of this paper is organized as follows. Section one gives a general introduction, in which the current stage of Islamic finance is outlined. Section two presents the growth of Islamic finance in the select countries of Middle East. Section three includes the literature review on the relationship between Finance and economic growth, and in particularly Islamic finance and economic growth. Section four explains the research problem, objective and importance. Section five illustrates the methodology of the research. Section six explores the results and the analysis of the study. Finally, section seven gives the conclusions of the study.

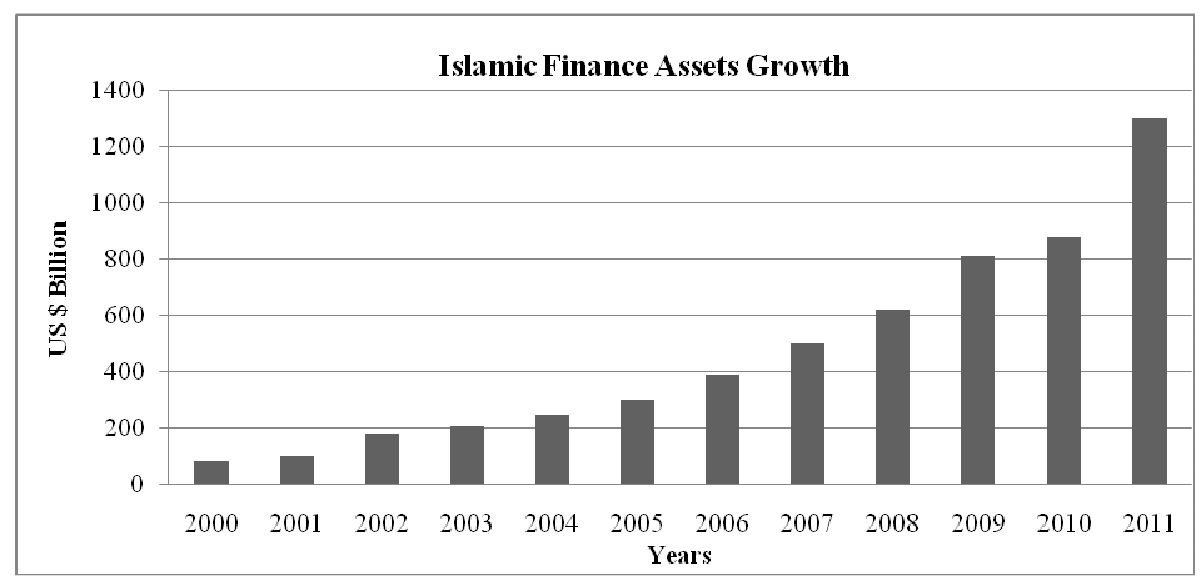

Fig 1. Islamic Finance Assets (2000-2011). Source: Deutsche Bank, (2011)

\section{Islamic Banking in the Select Countries of Middle East}

Global Islamic financing centers are mostly concentrated in the Middle East. United Arab Emirates has got 8.7 percent of total Islamic finance assets, followed by Bahrain 5.3 percent, and Qatar 4.8 percent share. Thus, we decided to study operations of Islamic banking and economic growth mainly in these three countries. Kingdom of Bahrain has the fastest growing economy in the Arab world. It also has the freest economy in the Middle East, and is twelfth freest overall in the world, based on the 2011 Index of Economic Freedom (Arabian business, 2013). Bahrain's banking and financial services sector, particularly Islamic banking, have benefited from the regional boom driven by demand for oil. Petroleum production and processing account is Bahrain's most exported product, accounting for $60 \%$ of export receipts, $70 \%$ of government revenues, and $11 \%$ of GDP (Heritage website, 2013). In recent years, Bahrain has rapidly become a global leader in Islamic finance, playing host to the largest concentration of Islamic financial institutions in the Middle East. It is at the forefront in the market for Islamic bonds (Sukuk), including short-term 
government Sukuk as well as leasing securities.

The market share of Islamic banks correspondingly increased from $1.8 \%$ of total banking assets in 2000 to 13.3\% in August 2012.

From November 2008, there are 417 financial institutions in Bahrain, including 59 IFIs. The banking sector consists of 88 conventional banks ( 24 retails and 64 wholesale) and 24 Islamic banks. The financial sector has a $22 \%$ share in GDP, making it the second most important industry in the country (Blominvest report, 2009).

The banking sector in Bahrain benefited from rapid economic growth. As a result, Islamic banks posted strong results over the past few years. During the period expanding from 1990 till 2008, combined assets of all Islamic banks generated a impressive growth from less than U.S.\$ 7,000 million in 1990 to more than U.S.\$ 37,000 million in 2008, with a cumulative increase up to $98.22 \%$ as shown in figure 2.

Qatar has the highest GDP per capita in the world as of 2012, according to World Fact book (World fact report, 2013). The economic growth of Qatar has been almost exclusively based on its petroleum and natural gas industries, which began in 1940. The banking sector in Qatar benefited from rapid economic growth. As a result, Islamic banks posted strong results over the past few years. During the period from 1990 till 2008, combined assets of Qatar Islamic banks, including Qatar International Islamic Bank, Qatar Islamic Bank, Masraf Al Rayan and First Finance Company, generated a impressive increase from less than U.S. \$ million 5,000 in 1990 to more than U.S \$ million 30,000 in 2008 with a cumulative increase of $98 \%$ as shown in figure 3 .

The Banking industry in Qatar consists of 11 local banks registered with the central bank and 7 foreign banks with branches in Qatar. Under the list of local banks, there are 4 Islamic banks fully operating under Shariah principles, 3 conventional banks with Islamic windows and 5 conventional banks with no Islamic banking operations.

Shariah-compliant assets, offered by both fully Islamic banks and Shariah-compliant windows (or branches) of conventional banks, experienced a strong growth of over 95\% in 2008 (Blominvest report, 2009).

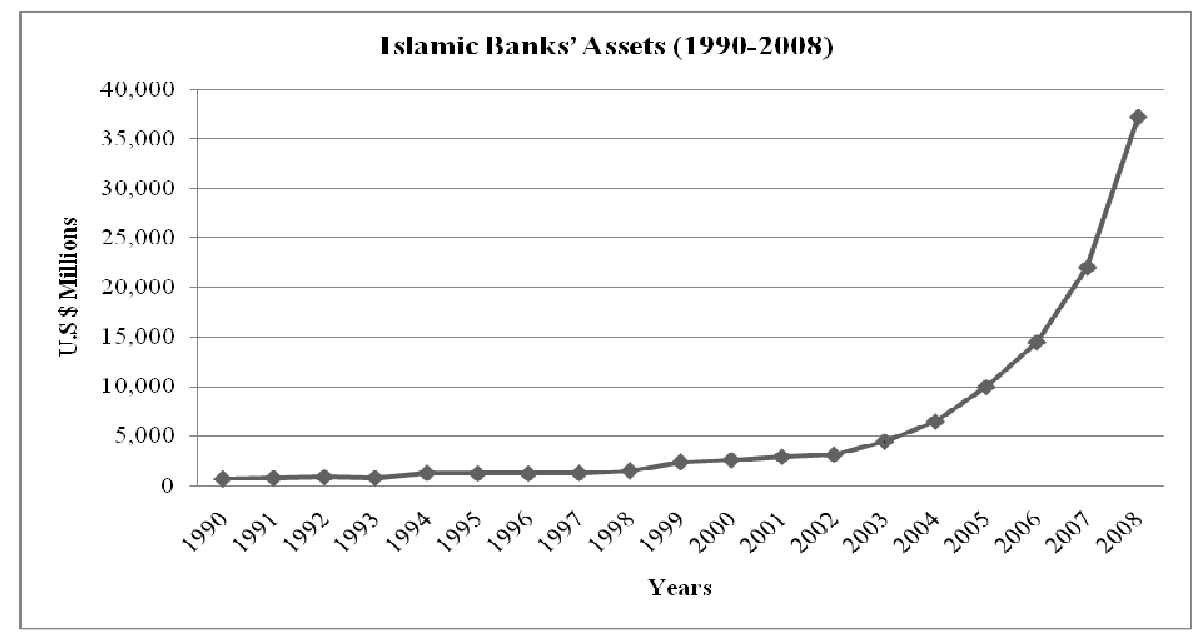

Fig 2. Islamic Banking Assets in Bahrain (1990-2008). Source: Developed by the researchers

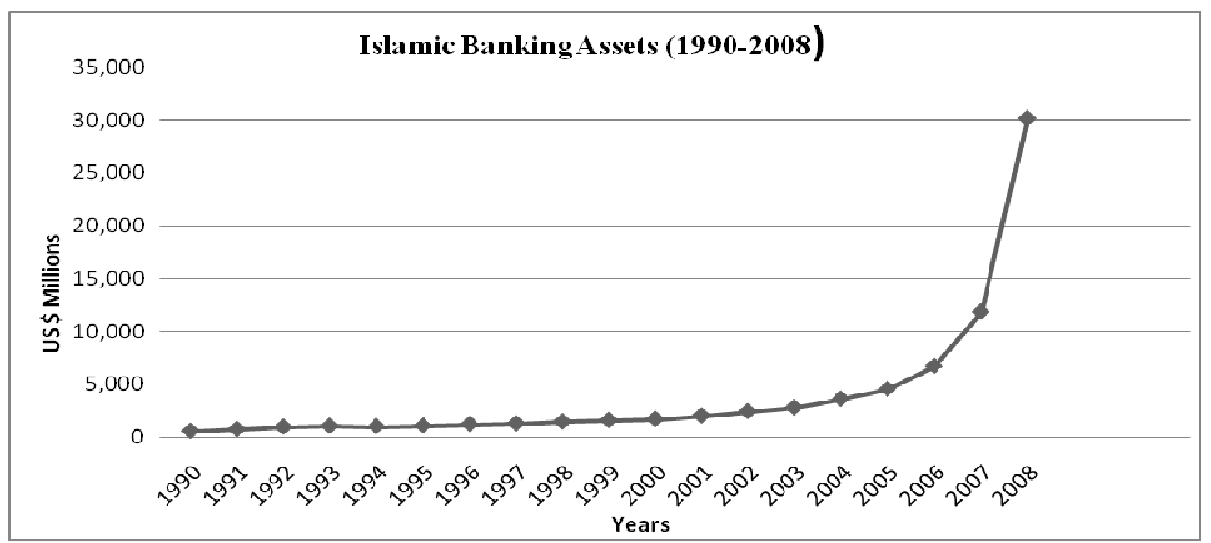

Fig 3. Islamic Banking Assets in Qatar (1990-2008). Source: Developed by the researchers

This trend is likely to continue as banks see Islamic banking as an opportunity to attract new clients. Islamic banking assets in Qatar witnessed a strong growth over the last couple of years, mainly driven by robust economic growth, increased demand for Shariah-based products and government willingness to promote the Islamic banking industry. Many underway projects, including petrochemical, housing and construction projects are demanding 
Shariah-based products, and this is likely to act as a future driver for Islamic banking, as the country has outlined public investment plans worth \$95bn for the period until 2016.

The United Arab Emirates (UAE) enjoys the highest economic growth rates in the Arab world. The UAE has an open economy with a high per capita income and a sizable annual trade surplus. The UAE banking sector, the largest in the Gulf Cooperation Council (GCC) by total assets, continued its positive trend in 2007(Deutsche Bank, 2011). Benefiting from a benign operating environment and a strong demand for credit; operating profits for most banks grew in double digits. Islamic banking has been continuously gaining popularity in the UAE. The two largest UAE Islamic banks are Dubai Islamic Bank (DIB) and Abu Dhabi Islamic Bank (ADIB). Conventional banks also have Shariah compliant subsidiaries and Islamic windows to facilitate Islamic transactions. The Islamic banking and finance sector has a good percentage of assets of banking system. For example, the assets of Islamic banks expanded by 27 percent during 2006-2010, much faster than the growth in assets of conventional banks. The UAE Islamic banking sector's performance continues to benefit from the buoyant economic environment. Total assets of Islamic banks in the UAE have increased from less than U.S \$ 1 million in 1990 to more than U.S \$ 58,000 million in 2010 with a cumulative increase of $98.47 \%$ as shown in figure 4.

Presently, there are 23 national banks and 22 foreign banks operating in the UAE. Out of the 23 national banks, 5 are full-fledged operating under Shariah principles and the remaining banks have both conventional and Islamic banking operations.

Islamic Banking Assets (1990-2010)

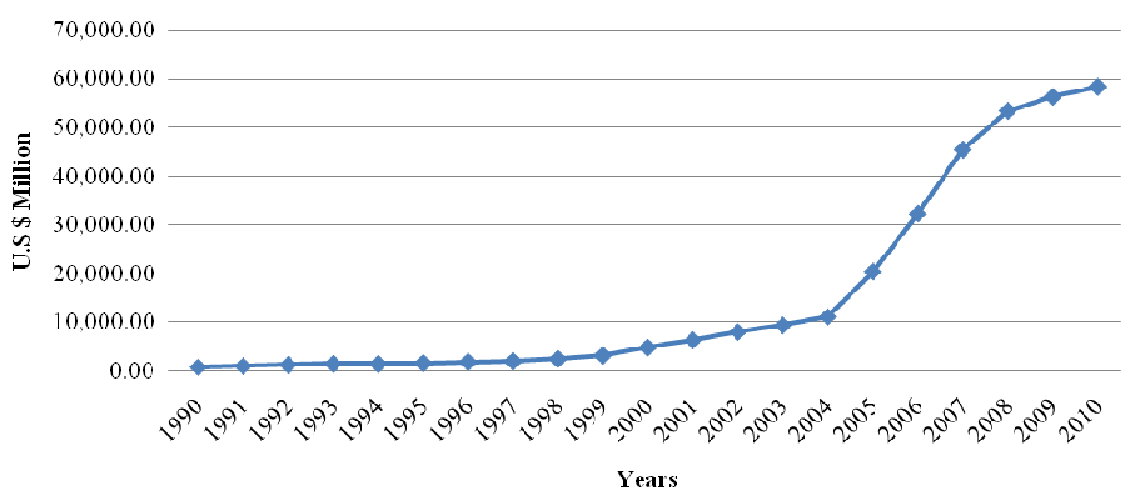

Fig 4. Islamic Banks Assets in UAE (1990-2010). Source: Developed by the researchers

\section{Literature Review}

The relationship between financial development and economic growth has been one of the most debated issues of whether the financial sector contributes to the real sector in the process of economic development. It is a controversial issue. Some authors consider finance an important element of growth (Schumpeter, 1934; Goldsmith, 1969; McKinnon, 1973, Shaw, 1973; King and Levine (1993), whilst for others it is only a minor growth factor (Robinson, 1952; Lucas, 1988). Schumpeter (1934) sees the banking sector as an engine of economic growth through its funding of productive investment. On the contrary, Lucas (1988) argues that the role of finance has been overstressed.

Patrick (1966) also contributed to this literature by identifying two possible patterns in the causal relationship between financial development and economic growth. The first one is called demand-following which means that the creation of modern financial institutions, their financial assets and liabilities, and related financial services is in response to the demand for these services by investors and savers in the real economy. This approach implies that financial system can thus support and sustain the leading sectors in the process of growth. Here, an expansion of the financial system is induced as a consequence of real economic growth. The second one is termed as supply-leading which means the creation of financial institutions and the supply of their financial assets, liabilities, and related financial services in advance of demand for them, especially the demand of entrepreneurs in the modern, growth-inducing sectors. Supply-leading has two functions: to transfer resources from traditional (non-growth) sectors to modern sectors, and to promote and stimulate an entrepreneurial response in these modern sectors. In addition, Gurley and Shaw (1955) and Goldsmith (1969) have argued that more developed financial markets promote economic growth by mobilizing savings and facilitating investment.

Explicitly or implicitly, in all studies, we note that an efficient financial system accelerates the economic development. The main contribution of financial system to materialize growth as it assures the functioning of an efficient and evolutionary payment system, and mobilizes the saving and improves its affectation to the investment. So the existence of a reliable and sound financial exchange system is a necessary for growth.

The financial sector plays a growth promoting role, if it is able to direct financial resources towards the sectors that demand those the most. When the financial sector is more developed, more financial resources can be allocated into productive use, and more physical capital gets formed, which will lead to economic growth. 
Odedokun (1992) favoured bidirectional causality between finance and growth. Both financial and economic developments are causally related where financial development causes economy to grow, and economic growth triggers financial sector to develop further. Masih (1996) supported demand following hypothesis where economic growth causes financial sectors to develop. As per this view, the more rapid the growth of real national income, the greater will be the demand by enterprises for external funds (the saving of others), and therefore, financial intermediation, as in most situations firms will be less able to finance expansion from internally generated depreciation allowance and retained profits. The financial system can thus support and sustain the leading sectors in the process of growth. In this case an expansion of the financial system is induced as a consequence of real economic growth or demand following. Levine and Zervos (1998) studied the empirical relationship between stock market development, banking development, and long-run economic growth. Their research showed that stock market liquidity and banking development are both positively and robustly correlated with contemporaneous and future rates of economic growth, capital accumulation and productivity growth.

Fase and Abma (2003) argued that expansion of the financial system could have a positive repercussion on economic growth. The financial sectors in this case act as supply leading to transfer resources from the traditional, low-growth sectors to the modern high-growth sectors and to promote and stimulate an entrepreneurial response in these modern sectors. Abu-Bader and Abu-Qarn (2005) examined the causal relationship between financial development and economic growth in Egypt for 1960-2001. They used Granger causality tests. They concluded that financial development promotes economic growth either through increasing investment efficiency or capital accumulation.

Tang (2006) used a modified growth model investigated whether financial development would have facilitated economic growth among the APEC countries from 1981 to 2000. Tang did this by specifically focusing on the effects of three aspects of financial development on economic growth: stock market, banking sector, and capital flow. Tang found that the level of stock market development would have no impact on the growth effect of capital flow increase among the APEC countries. In the banking sector his study shows that a well-functioning banking sector would only boost the growth effect of capital flow on the APEC developing countries.

Romeo-Avila (2007) also confirmed the positive impact of finance on growth. He investigated the relationship between finance and growth, with emphasis on the effect of financial deregulation and banking law harmonization on economic growth in the European Union. The study establishes that financial intermediation impacts positively the economic growth through three channels. Kenourgios and Samitas (2007) examined the long-run relationship between finance and economic growth for Poland, and concluded that credit to the private sector has been one of the main driving forces of long-run growth. Huang et Lin (2009) re-examined the dynamic relationship between financial development and economic growth on the dataset used in Levine et al. (2000). Using a novel threshold regression with the instrumental variables approach, they support a positive linkage between financial development and economic growth, and found that financial development has an important effect on growth in low-income countries.

Despite there are many studies investigating the relationship between financial development and economic growth, the studies that examine the role of Islamic financial development in economic growth are not too many. Some limited articles are done by some scholars from South-East Asia countries.

Furqani and Mulyany (2009) examined the dynamic interactions between Islamic banking and economic growth of Malaysia by employing the Co-integration test and Vector Error Correction Model (VECM) to see whether the financial system influences growth and growth transforms the operation of the financial system in the long-run. They found that in the short-run, only fixed investment that granger cause Islamic bank to develop for 1997:1-2005:4. Where as in the long-run, there is evidence of a bidirectional relationship between Islamic bank and fixed investment and there is evidence to support demand - following hypothesis of GDP and Islamic bank, where increase in GDP causes Islamic banking to develop and not vice versa.

Abduh and Chowdhury (2012) investigated the long run and dynamic relationship between Islamic banking development and economic growth in the case of Bangladesh. The quarterly time-series data of economic growth, total financing and total deposit of Islamic banking from Q1:2004 to Q2:2011 are used in their study. Using co-integration and Granger's causality method, Islamic banks' financing is found to have a positive and significant relationship with economic growth both in the long and short run. It implies that the development of Islamic banking is one of the policies, which should be considered by the government to improve their income.

The previous studies have showed that the development of Islamic financial system played a viable role in the economic growth for the country under consideration. But, the direction of the relationship between the flow of Islamic finance and economic growth differ from one country to another, related to the monetary policies of each country. Also, there are some drawbacks in the studies that showed the relationship between Islamic financial development and economic growth like most of the studies use short time periods and analysis of one Islamic bank for each country, besides; all the studies are done in South -East Asia counties. So, in this study, we investigate the total Islamic banks' financing for all fully fledged Islamic Banks in the selected countries from Middle East for a reasonable time so adequate number of data can be collected. The study selects the most important countries from Middle East in which Islamic finance has a footprint. 


\section{Research Problem and Questions}

There is no doubt that Islamic financial sector development plays an important role in the overall development of an economy. Although, there are many empirical studies that examined the relationship between finance and economic growth, but specific empirical studies on the relationship between Islamic finance and economic growth, are not too many.

To help in filling this gap in literature, this study tries to examine empirically the relationship between Islamic finance and economic growth, and its direction in the selected countries of Middle East. Further, the study gives an answer to the following research questions.

1. Does Islamic financial development have a significant relationship with economic growth in the long-term in selected countries of Middle East?

2. Does Islamic financial development lead to economic growth term in selected countries of Middle East?

3. Does Economic Growth lead to Islamic financial development term in selected countries of Middle East?

\section{Research Methodology}

Data set is extracted from Word Trade organization, Global Development Finance and Islamic Banks and Financial Institutions Information (IBIS), database for all Islamic banks' financing in term in selected countries of Middle East. To serve our purpose, appropriate variables were established and the long term relationships between those variables are determined by using econometric estimation methods. We use annually time series data for the variables- Islamic banks' financing through modes of financing as a proxy for financial sector and Real Gross Domestic Product (GDP) as a proxy for economic growth.
Based on the availability of data, two time periods are used. From 1990 to 2008 time series to examine the relationship between Islamic banks' financing and GDP for Bahrain and Qatar and from 1990 to 2010 time series to examine the relationship between Islamic banks' financing and GDP for UAE.

GDP is a common statistic to represent the income level of a particular country within a certain time range. Study about finance-growth nexus always use GDP as the principal variable reflecting economic growth.

The first step of the study is to determine the relationship between Islamic financial development and economic growth, and whether the series are stationary or not. In a model, for a correct evaluation, time series should be separated from all effects, and the series should be stationary. Thus, logarithms of time series were taken. We first analyzed the data by the unit-root test and found, regrettably, that the assumption no longer holds (i.e., the data are non-stationary). After a first-order differentiation test is processed, they all are in a stationary form. The co-integration analysis and the maximum likelihood test were performed to determine the number of co-integration vectors (Engle and Granger, 1987; Johansen, 1988; Johansen and Juselius, 1990). Once the long-term co-integration relationships between the variables have been confirmed, the Granger causality test is used to test the causality between Islamic bank' financing and economic growth. We use Eviews software to test and analyze the results.

\section{Analysis and Results}

\subsection{Descriptive Statistics}

Table (1) presents summary statistics about the variables used in the econometric analysis for the selected countries.

Table 1. Summary Statistics for selected countries of Middle East (1990-2008) and (1990-2010) periods

\begin{tabular}{|c|c|c|c|c|c|c|}
\hline & Bahrain & & Qatar & & UAE & \\
\hline Statistics (US \$ Millions) & GDP & IBF & GDP & $\mathrm{IBF}$ & GDP & IBF \\
\hline Mean & $8,975.566$ & $2,143.789$ & $26,081.03$ & $2,589.737$ & $132,502.4$ & $11,355.69$ \\
\hline Median & $6,621.190$ & $1,071.000$ & $12,393.13$ & $0,861.00$ & $103,312.0$ & $4,025.970$ \\
\hline Maximum & $21,902.89$ & $11,632.00$ & $115,019.8$ & $21,313.00$ & $314,845.0$ & $39,918.08$ \\
\hline Minimum & $4,229.790$ & 0.339 .0000 & $6,883.520$ & $0,510.00$ & $50,701.00$ & $0,739.970$ \\
\hline Std. Dev. & $5,034.908$ & $2,852.508$ & $29,345.49$ & $2,589.737$ & 88057.93 & $14,309.46$ \\
\hline observations & 19 & 19 & 19 & 19 & 21 & 21 \\
\hline
\end{tabular}

From table 1, we notice that the maximum value for IBFinancing in Bahrain in 2008 reached to 11,632.00 from $0,339.00$ in 1990 with standard deviation of $2,852.508$. For Qatar, we notice that the maximum value for IBFinancing in 2008 reached to $21,313.00$ from $0,861.00$ in 1990 with standard deviation of 2,589.737. The maximum value for IBFinancing in 2010 reached to $(39,918.08)$ from $(0,739.970)$ in 1990 with standard deviation of $(14,309.46)$ for UAE. The results of the selected countries give us an indication of high growth of the Islamic finance industry in the recent years. The statistics show that the median for GDP and IBFinancing is less than the mean, which indicates that the values are positively skewed.

\subsection{Unit Root Test}

Results of ADF and PP Tests applied to time series show that all series belong to economic growth and financial 
deepening indicators are not stationary at level. To make that

Series stationary, first differences of series have been taken. Failure to reject the null hypothesis of unit roots implies that the linear combination of the variables is non-stationary; hence we cannot pursue for the cointegation tests. ADF Test results are shown in Table 2:

Table 2. Unit Root Test

\begin{tabular}{|c|c|c|c|c|c|}
\hline & & $\begin{array}{l}\text { ADF Test } \\
\text { Level } 1\end{array}$ & First difference & $\begin{array}{l}\text { Phillip-Person Test } \\
\text { Level } 1\end{array}$ & First difference \\
\hline Country & Variable & $\begin{array}{l}\text { t- statistic } \\
\text { P value }\end{array}$ & $\begin{array}{l}\mathrm{t} \text { - statistic } \\
\text { P value }\end{array}$ & $\begin{array}{l}\text { t- statistic } \\
\text { P value }\end{array}$ & $\begin{array}{l}\mathrm{t} \text { - statistic } \\
\text { P value }\end{array}$ \\
\hline \multirow{2}{*}{ Bahrain } & GDP & $\begin{array}{l}0.529475 \\
0.9984\end{array}$ & $\begin{array}{l}-3.821091 \\
0.0413^{* *}\end{array}$ & $\begin{array}{l}0.897097 \\
0.9995\end{array}$ & $\begin{array}{l}-3.893848 \\
0.0363 * *\end{array}$ \\
\hline & IBFinancing & $\begin{array}{l}-1.266411 \\
0.8631\end{array}$ & $\begin{array}{l}-4.695598 * * \\
0.0087\end{array}$ & $\begin{array}{l}-1.266411 \\
0.8631\end{array}$ & $\begin{array}{l}-4.695598^{* *} \\
0.0087\end{array}$ \\
\hline \multirow{2}{*}{ Qatar } & GDP & $\begin{array}{l}-2.008458 \\
0.5618\end{array}$ & $\begin{array}{l}-4.889556^{* *} \\
0.0051\end{array}$ & $\begin{array}{l}-2.056949 \\
0.0015\end{array}$ & $\begin{array}{l}-5.039952 * * * \\
0.0038\end{array}$ \\
\hline & IBFinancing & $\begin{array}{l}-2.3974 \\
0.3688\end{array}$ & $\begin{array}{l}-4.7272 * * \\
0.01\end{array}$ & $\begin{array}{l}-2.4425 \\
0.35\end{array}$ & $\begin{array}{l}-15.8247 \\
0.0001^{* * *}\end{array}$ \\
\hline \multirow{2}{*}{ UAE } & GDP & $\begin{array}{l}-2.129647 \\
0.0546\end{array}$ & $\begin{array}{l}-3.371805^{* *} \\
0.0062\end{array}$ & $\begin{array}{l}-3.912819 * * * \\
0.0015\end{array}$ & $\begin{array}{l}-6.843614^{* *} \\
0.0000\end{array}$ \\
\hline & IBFinancing & $\begin{array}{l}-2.230132 \\
0.0456\end{array}$ & $\begin{array}{l}-3.491436 * * \\
0.0050\end{array}$ & $\begin{array}{l}-3.528265^{* * *} \\
0.0034\end{array}$ & $\begin{array}{l}-7.164660 * * \\
0.0000\end{array}$ \\
\hline
\end{tabular}

$*, * *, * * * \quad$ significant at $1 \%, 5 \%, 10 \%$ level respectively

The results of the table 2 indicate that the data at the first difference is stationary at $\alpha 1 \%, 5 \%$, and $10 \%$ level of significance respectively. For GDP variable, if $\mathrm{p}$ value is less than $\alpha$, then Ho is rejected, and the series is stationary.

From table 2, the first row shows that the $p$ value $(0.0413)$ is less than $\alpha(0.05)$ in ADF test for Bahrain. Similarly, for IBFinancing, the result from the second row shows that the $\mathrm{p}$ value $(0.0087)$ is less than $\alpha(0.05)$. We can notice also from
Qatar that the series is stationary since the $p$ value (0.0051) is less than $\alpha(0.05)$ in ADF test. Similarly, for IBFinancing, the result shows that the $p$ value (0.01) is less than $\alpha(0.05)$. Also, the series is stationary for UAE. This suggests that the null hypothesis is rejected for both variables in the three selected countries. Hence, the failure to reject the alternative hypothesis indicates that the two series are stationary.

\subsection{Johansen Co-Integration Test}

Table 3. Johansen's test (trace statistic)

\begin{tabular}{|c|c|c|c|c|c|}
\hline & & & Trace statistics & $\begin{array}{l}\text { Critic } \\
5 \%\end{array}$ & $1 \%$ \\
\hline \multirow{2}{*}{ Bahrain } & Null hypothesis & Ho: $r=0$ & 34.66095 & 15.41 & 20.04 \\
\hline & Alternative hypothesis & $\mathrm{H} 1: \mathrm{r} \geq 1$ & 12.03144 & 3.76 & 6.65 \\
\hline \multirow{2}{*}{ Qatar } & Null hypothesis & Ho: $r=0$ & $23.61007 * *$ & 15.41 & 20.04 \\
\hline & Alternative hypothesis & $\mathrm{H} 1: \mathrm{r} \geq 1$ & $4.991680^{* *}$ & 3.76 & 6.65 \\
\hline \multirow{2}{*}{ UAE } & Null hypothesis & Ho: $r=0$ & $16.52449 * *$ & 15.41 & 20.04 \\
\hline & Alternative hypothesis & $\mathrm{H} 1: \mathrm{r} \geq 1$ & 0.589393 & 3.76 & 6.65 \\
\hline
\end{tabular}

** Significant at $5 \%$ level

Table 4. Johansen's test (Max-Eigenvalue statistic)

\begin{tabular}{|c|c|c|c|}
\hline & Null Hypothesis & F statistics & Probability \\
\hline \multirow{2}{*}{ Bahrain } & IBF does not Granger Cause GDP & 4.87614 & $0.04321 * *$ \\
\hline & GDP does not Granger Cause IBF & 6.22222 & $0.02478 * *$ \\
\hline \multirow{2}{*}{ Qatar } & IBF does not Granger Cause GDP & 5.55321 & $0.01937 * *$ \\
\hline & GDP does not Granger Cause IBF & 4.53842 & $0.03306 * *$ \\
\hline \multirow{2}{*}{ UAE } & IBF does not Granger Cause GDP & 5.41605 & $0.01559 * *$ \\
\hline & GDP does not Granger Cause IBF & 2.02784 & 0.16842 \\
\hline
\end{tabular}

** Significant at $5 \%$ level

Table 3 shows the results of Johansson test for the long relationship between Islamic banks' financing and economic growth in the three selected countries of Middle East. The trace test rejects the null hypothesis if the trace statistics 
exceeds the critical value. For Bahrain, the first row of table 3 shows that the trace statistics (34.66095) exceeds the critical value of (15.41) at 95 percent confidence level. It suggests that the null hypothesis of no cointegrating relationships is rejected. The results for Qatar show that the trace statistics (23.61007) exceeds the critical value of (15.41) at 95 percent confidence level. For UAE, the trace statistics (16.52449) exceeds the critical value of (15.41) at 95 percent confidence level. It suggests that the null hypothesis of no cointegrating relationships is rejected. The results of the three countries confirm that there is a cointegrating relationship among the variables.

The eigenvalue test, tests the null hypothesis of $r$ versus $\mathrm{r}+1$ cointegrating relationships. This test rejects the null hypothesis if the eigenvalue test statistics exceeds the respective critical value. Table 4 presents the results from this test. Similarly for Bahrain, the result from the first row of table 4 shows that the eigenvalue test (22.62951) exceeds the critical value (14.07) at 95 percent confidence level. This suggests that the null hypothesis is rejected. Hence, the failure to reject the alternative hypothesis indicates that there is one cointegrating relationship among the variables. The eigenvalue test statistics (18.61839) exceeds the critical value (14.07) at 95 percent confidence level for Qatar. Similarly for UAE, statistics (15.93510) exceeds the critical value (14.07) at 95 percent confidence level. It suggests that the null hypothesis of no cointegrating relationships is rejected. The results confirm that there is a cointegrating relationship among the variables for the three countries of Middle East. The results from table 3 and 4, if read together, show that the null hypotheses of non-cointegation are rejected at 5 percent level of significance. This suggests that in the long run Islamic banks' financing will contribute in the growth of GDP of the three selected countries of Middle East.

\subsection{Granger Causality Test}

Statistics and probability values constructed under the null hypothesis of non-causality are reported in Table 5. It can be observed that there is a causal relationship between Islamic banks' financing and economic growth. However, our results show that two-way causality exists from Islamic banks' financing to economic growth and from GDP towards Islamic Banks' financing for Bahrain and Qatar, since the probability values 0.04321 and 0.02478 are less than 0.05 for Bahrain and the probability values 0.01937 and 0.03306 are less than 0.05 for Qatar. So, the null hypothesis is rejected, and it can be concluded that the higher flow of Islamic finance has led to the growth of the economy. At the same time, the development of the real sector economy stimulates Islamic banking institutions to change and develop for the two countries.

Table 5. Pair wise Granger Causality Tests (1990-2008)

\begin{tabular}{|c|c|c|c|c|c|}
\hline & & & Max-Eigenvalue & $\begin{array}{l}\text { Critic } \\
5 \%\end{array}$ & $1 \%$ \\
\hline \multirow{2}{*}{ Bahrain } & Null hypothesis & Ho: $r=0$ & 22.62951 & 14.07 & 18.63 \\
\hline & Alternative hypothesis & $\mathrm{H} 1: \mathrm{r}=1$ & 12.03144 & 3.76 & 6.65 \\
\hline \multirow{2}{*}{ Qatar } & Null hypothesis & Ho: $r=0$ & $18.61839 * *$ & 14.07 & 18.63 \\
\hline & Alternative hypothesis & $\mathrm{H} 1: \mathrm{r}=1$ & $4.991680 * *$ & 3.76 & 6.65 \\
\hline \multirow{2}{*}{ UAE } & Null hypothesis & Ho: $r=0$ & $15.93510 * *$ & 14.07 & 18.63 \\
\hline & Alternative hypothesis & $\mathrm{H} 1: \mathrm{r}=1$ & 0.589393 & 3.76 & 6.65 \\
\hline
\end{tabular}

** Significant at $5 \%$ level

For the UAE, It can be observed that there is a causal relationship between Islamic banks financing and economic growth. However, our results show that one-way causality exists only from Islamic banks financing to economic growth, since the probability value 0.01559 less than 0.05 . So, the null hypothesis is rejected, and it can be concluded that the higher flow of Islamic finance has led to the growth of the economy in the UAE.

\section{Conclusion}

This paper makes an attempt to examine the relationship between the development of Islamic financial system and economic growth in the long-term in the selected countries of Middle East. We analyzed empirically the relationship between Islamic banks' financing and economic growth using econometric analysis. Since, the variables in this paper are stationary; therefore, the Johansen's co-integration technique has been applied. The co-integration results provide evidence of a unique cointegrating vector. In other words, there is a long-term stable relationship between Islamic banks' financing and economic growth in the three countries under the study. That means Islamic banks' financing and economic growth move together in the long-run. That means Islamic banks' financing and economic growth move together in the long-run for the selected countries of Middle East. It is proved that the Middle East has benefited from strong banking system.

We also find that the causality relation exist in a bi-directional relationship from Islamic banks' financing to economic growth and vice versa for Bahrain and Qatar. We also find that the causality relation exist in the Islamic banks' financing to economic growth in a unique direction from the development of financial system to economic growth, but not in the opposite direction in UAE. Our results also indicate that improvement of the Islamic financial 
institutions in the Middle East will benefit economic development, and it is critical in the long run for the economic welfare, and also for poverty reduction. The results of study are quite significant as it is one of the pioneering studies of Islamic finance.

\section{References}

[1] Abduh, M. and Omar, M. (2012),"Islamic banking and economic growth: the Indonesian experience", International Journal of Islamic and Middle Eastern Finance and Management, Vol. 5, 1, pp. $35-47$.

[2] Arabian business website, (2013). Accessed on Nov.2013 through the website www.arabianbusiness.com/bahrain-expected-bustle-149877. html.

[3] Beck, T., Levine, R. and Loayza, N. (2000), "Finance and the Sources of Growth", Journal of Financial Economics, Vol. 58, pp.261-300.

[4] Bekaert, G. Harvey, C. and Lundblad, C. (2001), "Emerging Equity Markets and Economic Development", Journal of Development Economics, Vol.66, pp. 465-504.

[5] Blominvest bank report, (2009), "Islamic Banking in the MENA region", February, UAE.

[6] Deutsche Bank, (2011), "Global Islamic Banking Report", November, London, UK.

[7] Dickey, D. and Fuller, W. (1981), "Likelihood Ratio Statistics for Auto- regressive Time Series with a Unit Root", Econometric journal Vol.49 (4), pp. 1057-1072.

[8] Ernst \& Young. (2011a), "Islamic Funds \& Investments Report: Achieving Growth in Challenging Times", June, http://www.ey.com/Publication/vwLUAssets/IFIR_2011/\$FI $\mathrm{LE} /$.

[9] Fase, M. M. G. and Abma, R. C. N. (2003), "Financial Environment and Economic Growth in Selected Asian Countries", Journal of Asian Economics, Vol.14, pp.11-21.

[10] Goldsmith, R. (1969), "Financial Structure and Economic Growth in Advanced Countries", National Bureau Committee for Economic Research, Capital Formation and Economic Growth, Princeton, University Press.

[11] Hasan, M. and Dridi. J., (2010), The Effect of Global Financial Crisis on Islamic and Conventional Banks: A Comparative Study, IMF Working Paper,WP/10/201

[12] Huang, H. and Shu-Chin, Lin. (2009),"Non-Linear Finance-Growth Nexus: A threshold with Instrumental Variable Approach", Economics of Transition, Vol. 17(3), pp. 439-466.

[13] Heritage website report,(2013), Accessed on Nov.2013 through the website www.heritage.org/index/
[14] Furqani, H. and Mulyany, R. (2009), Islamic Banking and Economic Growth: Empirical Evidence from Malaysia, Journal of Economic Cooperation, 30, 2, 59-74.

[15] Kenourgios, D. and Samitas, A. (2007), "Financial Development and Economic Growth in a Transition Economy: Evidence for Poland", Journal of Financial Decision Making, Vol.3 (1), pp.

[16] Levine, R. (2005)," Finance and Growth: Theory and Evidence", In: Handbook of Economic Growth, ed. by P. Aghion and S. Durlauf, vol.1, pp.865-934, Elsevier.

[17] Levine, R. (1993), "Financial Development and Economic Growth: Views and Agenda", Journal of Economic Literature, Vol. 35(2), pp. 688-726.

[18] R.E., (1988),"On the Mechanics of Economic Development", Journal of Monetary Economics, Vol. 22(1), pp. 3-42.

[19] Lucas R.E., (1988),"On the Mechanics of Economic Development", Journal of Monetary Economics, Vol. 22(1), pp. 3-42.

[20] Majid, S.A. and Kassim, S. (2008), "Islamic finance and economic growth: The Malaysian experience", In: Kuala Lumpur Islamic Finance Forum, Kuala Lumpur.

[21] McKinnon R.I., (1973), "Money and Capital in Economic Development", the Brookings Institution, Washington, DC.

[22] Odedokun, M. (1992),"Supply-Leading and Demand-Following Relationships between Economic Activity and Development Banking in Developing Countries: An Empirical Analysis", Singapore Economic Review, Vol. 37, pp. 46-58.

[23] Patrick, H.T. (1966), "Financial development and economic growth in developing countries", Economic Development and Cultural Change, Vol. 14 No. 2, pp. 174-89.

[24] Osservatore, Vatican (2009), Islamic Banking May Help Overcome Crisis, Press Release

[25] Romeo, A. (2007), "Finance and Growth in the EU: New Evidence from the Harmonization of the Banking Industry", Journal of Banking and Finance, Vol. 31, pp.1937-1954.

[26] Robinson, J. (1952), "The Generalization of the General Theory in the Rate of Interest and Other Essays", London: Macmillan.

[27] Schumpeter, J.A. (1934),"The Theory of Economic Development", Cambridge, MA, Harvard University Press.

[28] Shaw, E.S. (1973), "Financial Deepening in Economic Development", Oxford University Press, New York.

[29] Tang, D. (2006), "The Effect of Financial Development on Economic Growth, Evidence from the APEC Countries", Applied Economics, Vol. 38(16), pp.1889-1904.

[30] World Fact book report,(2013), Accessed on Sep.2013 through the website https://www.cia.gov/library/publications/the-world-factbook /rankorder/2004rank.html 